\title{
Reassessing the role for lamivudine in chronic hepatitis B infection: A four-year cohort analysis
}

\author{
Tahir Shaikh BSc MDCMํㄹ , Curtis Cooper MD FRCPC ${ }^{1,2}$
}

T Shaikh, C Cooper. Reassessing the role for lamivudine in chronic hepatitis B infection: A four-year cohort analysis. Can J Gastroenterol 2012;26(3):148-150.

BACKGROUND/OBJECTIVES: Lamivudine is readily available and inexpensive. Guidelines recommend other antiviral medications because they achieve superior virological suppression with less resistance. These data are based on clinical trial populations and may not be representative of typical hepatitis B virus (HBV) populations. The authors assessed lamivudine in maintaining long-term viral suppression in an adherent, frequently monitored, noninvestigational HBVinfected population.

METHODS: All HBV patients ( $\mathrm{n}=369)$ between 2000 and 2010 were evaluated in a retrospective, single-centre study. Virological response was defined by complete suppression of HBV DNA $(<400$ copies $/ \mathrm{mL})$ and was assessed at six to 12 month intervals over four years. Enzymatic and serological outcomes, as well as treatment failures were assessed.

RESULTS: Forty-seven patients (36 men; mean age 44 years, mean alanine aminotransferase level $123 \mathrm{U} / \mathrm{L}$; METAVIR stage 3/4 [n=21], treatment naive $[\mathrm{n}=41]$ ) received lamivudine $100 \mathrm{mg}$ to $300 \mathrm{mg}$ daily. The mean pretreatment viremia was $5.19 \log _{10}$ copies $/ \mathrm{mL}$, and was above the limit of detection $\left(>6.91 \log _{10}\right.$ copies $\left./ \mathrm{mL}\right)$ in 11 patients $(23 \%)$. The mean ( \pm SD) dosing duration was $32 \pm 22$ months. Virological suppression was achieved in $45(96 \%)$ patients. Mean viremia declined to $3.06 \log _{10}$ copies $/ \mathrm{mL}(\mathrm{n}=27)$ and $2.68 \log _{10}$ copies $/ \mathrm{mL}$ $(n=18)$ at 12 and 48 months, respectively, with $78 \%$ and $88 \%$ with undetectable viremia at these time points, respectively. The mean alanine aminotransferase level declined to $31 \mathrm{U} / \mathrm{L}$ and $36 \mathrm{U} / \mathrm{L}$ at 12 and 48 months, respectively. Seven of 13 (54\%) hepatitis B e antigen-positive patients seroconverted. The treatment failure rate was $11 \%$.

CONCLUSIONS: In a selected group of HBV patients, successful long-term viremia suppression was achieved with low treatment failure rates. With strict dosing adherence and monitoring for virological breakthrough, sustained virological suppression can be reliably achieved with lamivudine in carefully selected patients.

Key Words: 3TC; Antivirals; HBV; Heptovir; Lamivudine; Viremia

\author{
La réévaluation du rôle de la lamivudine dans \\ l'infection chronique par l'hépatite B : une analyse \\ de cohorte de quatre ans
}

HISTORIQUE ET OBJECTIFS : La lamivudine est facilement disponible et peu coûteuse. Dans les lignes directrices, on recommande d'autres antiviraux, car ils assurent une suppression virologique supérieure et une résistance moindre. Ces données se fondent sur des populations en essai clinique et ne sont peut-être pas représentatives des populations atteintes du virus de l'hépatite B (VHB). Les auteurs ont évalué la lamivudine pour maintenir la suppression virale à long terme au sein d'une population infectée par le VHB qui respectait le traitement, faisait l'objet d'un suivi fréquent et n'était pas expérimentale.

MÉTHODOLOGIE : Les chercheurs ont évalué tous les patients atteints du VHB (n=369) entre 2000 et 2010 dans le cadre d'une étude rétrospective monocentre. Ils ont défini la réponse virologique par une suppression complète du VHB dans l'ADN (moins de 400 copies $/ \mathrm{mL}$ ) et l'ont évaluée à intervalles de six à 12 mois pendant quatre ans. Ils ont également évalué les issues enzymatiques et sérologiques, ainsi que les échecs thérapeutiques.

RÉSULTATS : Quarante-sept patients (36 hommes; âge moyen de 44 ans, taux moyen d'alanine aminotransférase de $123 \mathrm{U} / \mathrm{L}$; étape de METAVIR $3 / 4$ [n=21], naïfs au traitement [n=41]) ont reçu de $100 \mathrm{mg}$ à $300 \mathrm{mg}$ de lamivudine tous les jours. Leur virémie moyenne avant le traitement était de $5,19 \log _{10}$ copies/mL et se situait au-delà des limites de détection (plus de $6,91 \log _{10}$ copies $/ \mathrm{mL}$ ) chez 11 patients $(23 \%)$. La durée moyenne $( \pm E$ E $)$ du dosage était de $32 \pm 22$ mois. Les chercheurs ont obtenu la suppression virologique chez $45(96 \%)$ patients. La virémie moyenne a diminué à $3,06 \log _{10}$ copies $/ \mathrm{mL}(\mathrm{n}=27)$ et à $2,68 \log _{10}$ copies $/ \mathrm{mL}(\mathrm{n}=18)$ à 12 et 48 mois, respectivement, dont $78 \%$ et $88 \%$ avaient une virémie non décelable à ces moments respectifs. Le taux moyen d'alanine aminotransférase a chuté à $31 \mathrm{U} / \mathrm{L}$ et $36 \mathrm{U} / \mathrm{L}$ à 12 et 48 mois, respectivement. Sept des 13 (54 \%) patients atteints d'hépatite B positifs à l'antigène e se sont séroconvertis. Le taux d'échec de traitement s'élevait à $11 \%$.

CONCLUSIONS : Dans un groupe sélectionné de patients atteints $\mathrm{du} \mathrm{VHB}$, les chercheurs ont obtenu la suppression de la virémie à long terme et un faible taux d'échec thérapeutique. Avec un respect rigoureux du dosage et un suivi des percées virologiques, la lamivudine peut assurer une suppression virologique fiable chez des patients soigneusement sélectionnés.

Lamivudine resistance rates of up to $70 \%$ at four years were reported in a pooled analysis of four multicentre studies (4). Patients enrolled in these studies had very high pretreatment viral loads, often exceeding 10 times the lower limit of their inclusion criteria $(5,6)$. These data, however, may not be generalizable to typical clinic populations. Some patients with lower HBV DNA levels may still require antiviral therapy, specifically those with advanced liver fibrosis. The risk for lamivudine resistance in this patient population is likely much lower, but not well evaluated.

Because of formulary restrictions in Canadian public drug plans, lamivudine is often the only readily available treatment option. Given the relative inexpense and ease of access to this medication compared with other HBV antivirals in Canada (7), it is important to identify populations in which lamivudine is effective despite the known HBV suppression.

\footnotetext{
${ }^{1}$ Department of Medicine, University of Ottawa; ${ }^{2}$ The Ottawa Hospital Viral Hepatitis Program - Division of Infectious Disease, Ottawa, Ontario Correspondence: Dr Curtis Cooper, The Ottawa Hospital Division of Infectious Disease, The Ottawa Hospital General Campus, Room G12,

501 Smyth Road, Ottawa, Ontario K1H 8L6.Telephone 613-737-8924, fax 613-737-8164, e-mail ccooper@ottawahospital.on.ca

Received for publication July 23, 2011. Accepted August 14, 2011
} 
limitations. Accordingly, we assessed lamivudine effectiveness in maintaining long-term viral suppression in an adherent, frequently monitored, noninvestigational HBV-infected population.

\section{METHODS}

\section{Patient selection}

The present retrospective single-centre study evaluated HBV-infected patients referred to The Ottawa Hospital (Ottawa, Ontario) Viral Hepatitis Program between January 2000 and 2010. Patients with chronic HBV, defined as surface antigen and HBV DNA positive, were identified using a clinical database. The present study was approved by the Ottawa Hospital Research Ethics Board (2004-196).

\section{Data collection}

Basic demographic information (age, sex, race, immigrant status and country of origin), pregnancy status, HIV and hepatitis C coinfection status, HBV exposure risk factors and previous HBV antiviral use data were collected. Baseline alanine aminotransferase (ALT), aspartate aminotransferase (AST) levels, and hepatitis B e antigen and antibody $(\mathrm{HBe} \mathrm{Ag} / \mathrm{HBeAb})$ status and HBV DNA $\left(\log _{10}\right.$ copies $\left./ \mathrm{mL}\right)$ was obtained for all patients. Quantitative HBV DNA levels were typically measured at three, six and 12 months, and then at six-to 12 -month intervals while on therapy using an in-house assay. Data regarding baseline liver biopsy stage and grade were also collected. Indication for starting lamivudine, dose, treatment duration and reasons for discontinuing therapy were recorded.

Viral suppression was assessed as the primary outcome measure. Virological response to therapy was defined as complete suppression of HBV DNA $(<400$ copies/mL [the lower limit of detection of the assay]). Virological breakthrough was defined as detectable viremia after complete virological suppression or a $1.0 \log _{10}$ increase in viremia from on-treatment nadir. Secondary outcomes included reduction in ALT and AST levels, and HBeAg seroconversion.

\section{Statistical analysis}

Descriptive analysis was conducted. Dichotomous variables were evaluated using $\chi^{2}$ tests, while continuous variables were assessed using $t$ tests. PASW Statistics version 18.0 (SPSS, IBM Corporation, USA) was used for the analyses.

\section{Study population}

\section{RESULTS}

Forty-seven patients ( 36 men, mean $[ \pm$ SD] age $44 \pm 13$ years) who received lamivudine in $100 \mathrm{mg}(\mathrm{n}=10), 150 \mathrm{mg}(\mathrm{n}=35)$ or $300 \mathrm{mg}$ $(n=2)$ once-daily doses were evaluated in the present analysis. The key patient characteristics are summarized in Table 1. Twenty-seven other patients were excluded for the following reasons: occult HBV infection $(n=2)$; early loss to follow-up $(n=7)$; no pretreatment measure of HBV DNA $(n=4)$; or HBV DNA reported in $\mathrm{pg} / \mathrm{mL}(\mathrm{n}=14)$.

The mean pretreatment viral load was $5.19 \pm 1.45 \log _{10}$ copies $/ \mathrm{mL}$ (range $2.60 \log _{10}$ copies $/ \mathrm{mL}$ to $6.91 \log _{10}$ copies $/ \mathrm{mL}$ ). Pretreatment viremia was above the upper limit of detection $\left(>6.91 \log _{10}\right.$ copies $\left./ \mathrm{mL}\right)$ in 11 patients $(23 \%)$. Mean baseline liver enzyme levels were two times the upper limit of normal (ALT $124 \pm 209 \mathrm{U} / \mathrm{L}$ [range $12 \mathrm{U} / \mathrm{L}$ to $1181 \mathrm{U} / \mathrm{L}$ ]; AST $78 \pm 113 \mathrm{U} / \mathrm{L}$ [range $17 \mathrm{U} / \mathrm{L}$ to $503 \mathrm{U} / \mathrm{L}$ ). At the initiation of therapy, 13 patients were $\mathrm{HBeAg}$ positive, 33 were $\mathrm{HBeAg}$ negative and one subject was undefined.

\section{Response to lamivudine therapy}

The mean treatment duration was $32 \pm 21$ months (range three to 75 months). At the time of the data censoring, 33 patients were on active treatment and 14 had discontinued lamivudine for reasons listed in Table 1.

Complete virological suppression was achieved in 45 patients (96\%). The mean time to virological suppression was $4 \pm 2$ months (range one to 12 months). The mean viremia declined to $3.06 \log _{10}$ copies/mL $(\mathrm{n}=27)$ at 12 months, and $2.66 \log _{10}$ copies $/ \mathrm{mL}$ at 48 months

\section{TABLE 1}

Baseline characteristics of chronic hepatitis B virus-infected patients receiving lamivudine $(n=47)$

\begin{tabular}{lc}
\hline Male sex & 36 \\
Age, years, mean \pm SD & $44 \pm 13$ \\
Immigrant ( $\mathrm{n}=42)$ & \\
Asian & 28 \\
East Indian & 3 \\
African & 9 \\
European & 1 \\
Middle Eastern & 1 \\
Coinfection & \\
HIV & 1 \\
Hepatitis C & 0 \\
Pregnancy & 6 \\
Previous treatment (n=6) & \\
Lamivudine & 5 \\
Tenofovir & 1 \\
METAVIR biopsy stage* (n=36) & \\
0 & 4 \\
1 & 5 \\
2 & 6 \\
3 & 14 \\
4 & 7 \\
Discontinuation of therapy (n=14) & \\
Side effects & \\
Completion of lymphoma chemotherapy & 1 \\
Enzymatic and virological treatment response & 1 \\
Postpartum & 3 \\
Normal repeat biopsy & \\
Hepatitis B e antigen seroconversion & 4 \\
Virological breakthrough & 2 \\
\hline & \\
\hline
\end{tabular}

Data presented as $n$ unless otherwise indicated. *Two subjects had known cirrhosis diagnosed on pretreatment magnetic resonance imaging. Biopsies were not pursued in these patients.

$(\mathrm{n}=18)$. Twenty-one $(78 \%)$ and $15(88 \%)$ patients had undetectable viral loads at 12 and 48 months, respectively. The mean ALT level declined to $31 \pm 15 \mathrm{U} / \mathrm{L}$ (range $13 \mathrm{U} / \mathrm{L}$ to $68 \mathrm{U} / \mathrm{L}[\mathrm{n}=30]$ ) and $36 \pm 37 \mathrm{U} / \mathrm{L}$ (range $14 \mathrm{U} / \mathrm{L}$ to $84 \mathrm{U} / \mathrm{L}[\mathrm{n}=18]$ ) at 12 and 48 months, respectively. The mean AST level declined to $28 \pm 15 \mathrm{U} / \mathrm{L}$ (range $11 \mathrm{U} / \mathrm{L}$ to $91 \mathrm{U} / \mathrm{L}$ $[\mathrm{n}=36])$ and $24 \pm 7 \mathrm{U} / \mathrm{L}$ (range $11 \mathrm{U} / \mathrm{L}$ to $41 \mathrm{U} / \mathrm{L}[\mathrm{n}=21]$ ). Seven of 13 (54\%) HBeAg-positive patients seroconverted to HBeAb-positive status. The median time to seroconversion was 11 months (range eight to 43 months).

\section{Treatment failure}

Treatment failure occurred in five patients (11\%) (Figure 1). Three patients were treatment naive, and two had previous lamivudine exposure. Patients 0980 and 1446 were started on oral lamivudine therapy for advanced fibrosis identified on liver biopsy. Complete virological suppression was achieved in these two patients at three months, with subsequent virological breakthrough at six and 12 months, respectively. Suboptimal adherence to therapy may have been a contributing factor in one case. Patient 1200 was started on therapy to prevent a flare of HBV infection while undergoing treatment for non-Hodgkin's lymphoma. This HBeAg-negative patient had persistent high-level viremia and was unable to achieve virological suppression despite excellent adherence. HBeAg-positive patients 0561 and 0643 had previous exposure to lamivudine. Both resumed lamivudine due to detectable viremia. Patient 0643 did not achieve virological suppression despite a measurable decrease in viral load over the course of 10 months. Patient 0561 achieved complete virological suppression at 12 months, with subsequent virological breakthrough at 18 months. No enzymatic flares were detected in these five patients at any time while 


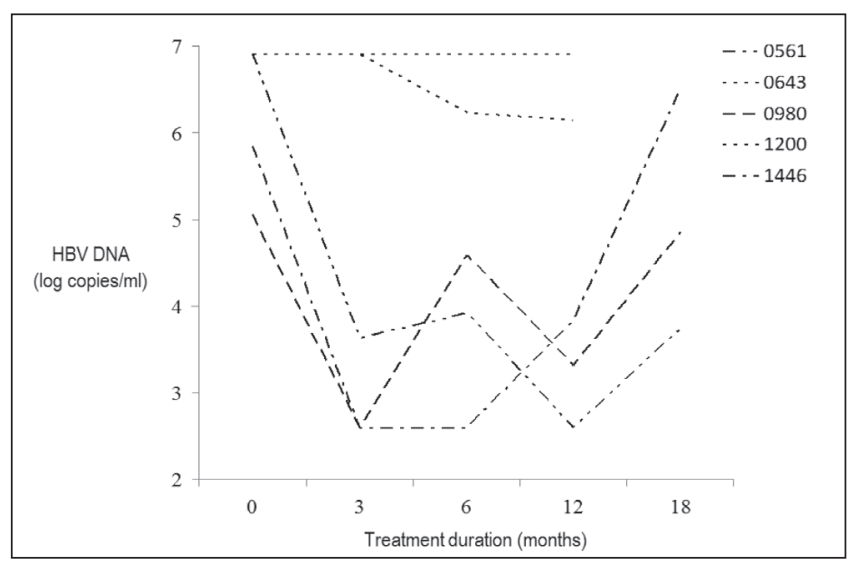

Figure 1) Patterns of virological nonresponse and failure in lamivudine recipients. Lower limit of detection $=2.6 \log _{10}$ copies $/ \mathrm{mL}$. HBV Hepatitis $B$ virus

on treatment or at the time of virological breakthrough. Genotypic resistance testing was not available for these cases.

\section{DISCUSSION}

Successful treatment of chronic HBV infection involves the judicious selection of the appropriate antiviral agent in appropriate patients. In Canada, the selection of HBV antivirals is unfortunately as much an economic decision as it is a clinical one. As a consequence of lower cost and greater availability, lamivudine continues to be used despite lower virological potency and higher drug resistance rates compared with other oral HBV antiviral medications. Canadian physicians involved in the management of HBV treated $58 \%$ of their treatment-naive HBV patients under public drug coverage with lamivudine (7). These data reinforce the need for further study to identify the specific demographic and biochemical characteristics of patients for which lamivudine would be highly effective.

Our results suggest that sustained HBV DNA suppression in patients with chronic HBV infection can be achieved with lamivudine, and with low rates of treatment failure. Normalization of serum aminotransferase levels were achieved in all patients. The rate of $\mathrm{HBeAg}$ seroconversion was similar to the rates reported in the current literature $(3,5,8)$. Contrary to current practice guidelines, our analysis supports the use of lamivudine as a viable first-line agent, assuming appropriate preselection.

The Canadian consensus guidelines on the management of chronic HBV recommend entecavir as first-line therapy because of the compelling clinical trial data in its favour (1). Patients enrolled in these clinical trials are not necessarily representative of the chronic HBV patient managed in typical North American clinics. Most subjects identified in our analysis had advanced liver fibrosis despite a lower overall pretreatment HBV viral load and aminotransaminase levels. The high rate of virological response to therapy with low rates of treatment failure in our study population suggests that lamivudine can be reasonably considered as an initial option for patients with viral loads below the upper limit of detection.
Several limitations of the present study are acknowledged. The study population was selected at baseline for characteristics that our clinic physicians predicted would result in success with lamivudine treatment. This bias should be considered when applying our results to other clinical populations. The relatively small sample size does not allow for subgroup analyses (eg, lamivudine dose, HBeAg positive versus $\mathrm{HBeAg}$ negative, low versus high pretreatment viral load). These data would help to identify factors for the selection of patients that may benefit with more favourable outcomes using lamivudine. Virological breakthrough or failure to achieve virological suppression were used as surrogate outcome measures for resistance because genetic testing for resistance mutations was not available.

Given the increasing burden of HBV in Canada and the limited therapeutic options available to clinicians, it is important to identify patients who would be best managed with lamivudine (9). Our data suggest that lamivudine can be successfully used in a well-selected, adherent population. Further study is required to better determine favourable patient characteristics for which lamivudine would be of greatest benefit.

ACKNOWLEDGEMENTS: The authors acknowledge the contributions of the patients and staff of The Ottawa Hospital Viral Hepatitis Program. Dr Cooper acknowledges The Ottawa Hospital Department of Medicine for funding support and David Mackie for assistance with manuscript preparation.

\section{REFERENCES}

1. Sherman M, Shafran S, Burak K, et al. Management of chronic hepatitis B: Consensus guidelines. Can J Gastroenterol 2007;21(Suppl C):5C-24C.

2. Berg T, Marcellin P, Zoulim F, et al. Tenofovir is effective alone or with emtricitabine in adefovir-treated patients with chronic-hepatitis B virus infection. Gastroenterology 2010;139:1207-17.

3. Chang TT, Gish RG, de Man R, et al. A comparison of entecavir and lamivudine for HBeAg-positive chronic hepatitis B. N Engl J Med 2006;354:1001-10.

4. Lai CL, Dienstag J, Schiff E, et al. Prevalence and clinical correlates of YMDD variants during lamivudine therapy for patients with chronic hepatitis B. Clin Infect Dis 2003;36:687-96.

5. Lai CL, Chien RN, Leung NW, et al. A one-year trial of lamivudine for chronic hepatitis B. Asia Hepatitis Lamivudine Study Group. N Engl J Med 1998;339:61-8.

6. Schalm SW, Heathcote J, Cianciara J, et al. Lamivudine and alpha interferon combination treatment of patients with chronic hepatitis B infection: A randomised trial. Gut 2000;46:562-8.

7. Marotta P, Lucas K. Management of hepatitis B: A longitudinal national survey - impact of the Canadian hepatitis B consensus guidelines. Can J Gastroenterol 2010;24:537-542.

8. Liaw YF, Sung JJ, Chow WC, et al. Lamivudine for patients with chronic hepatitis B and advanced liver disease. $\mathrm{N}$ Engl J Med 2004;351:1521-31.

9. Minuk G, Uhanova J. Chronic hepatitis B infection in Canada. Can J Infect Dis 2001;12:351-6. 


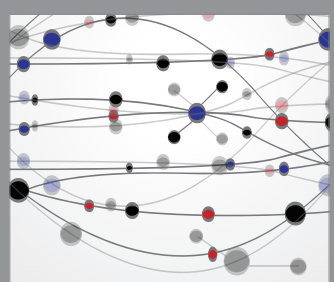

The Scientific World Journal
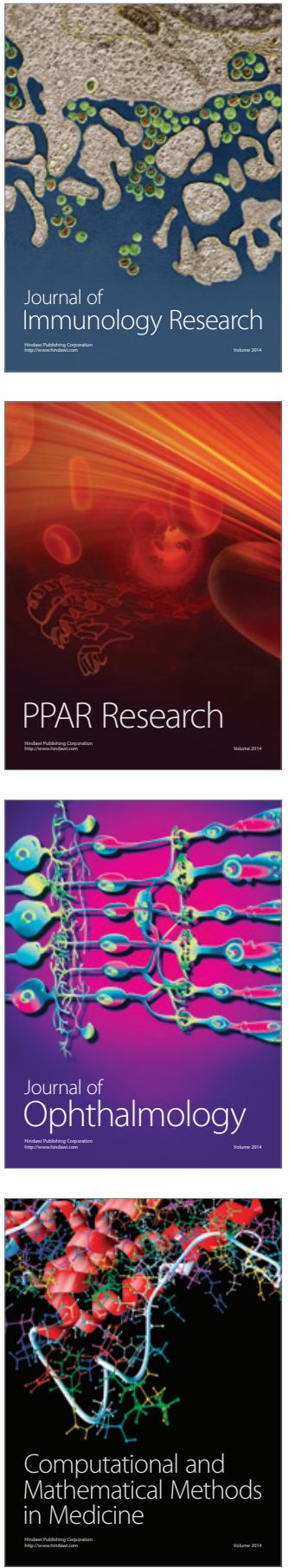

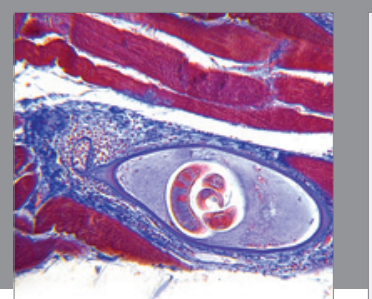

Gastroenterology Research and Practice

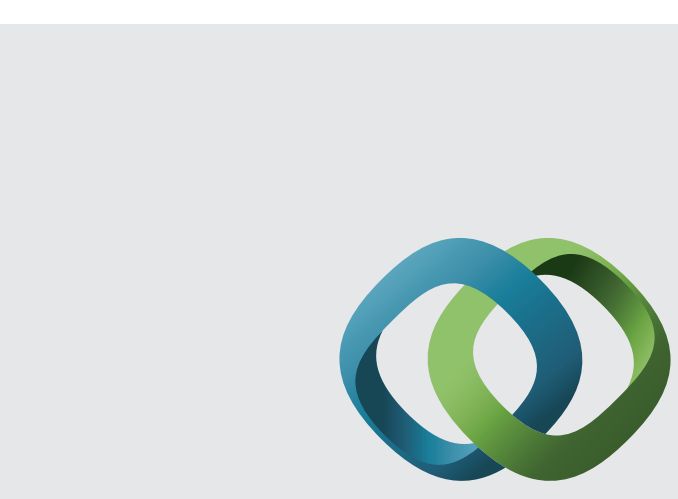

\section{Hindawi}

Submit your manuscripts at

http://www.hindawi.com
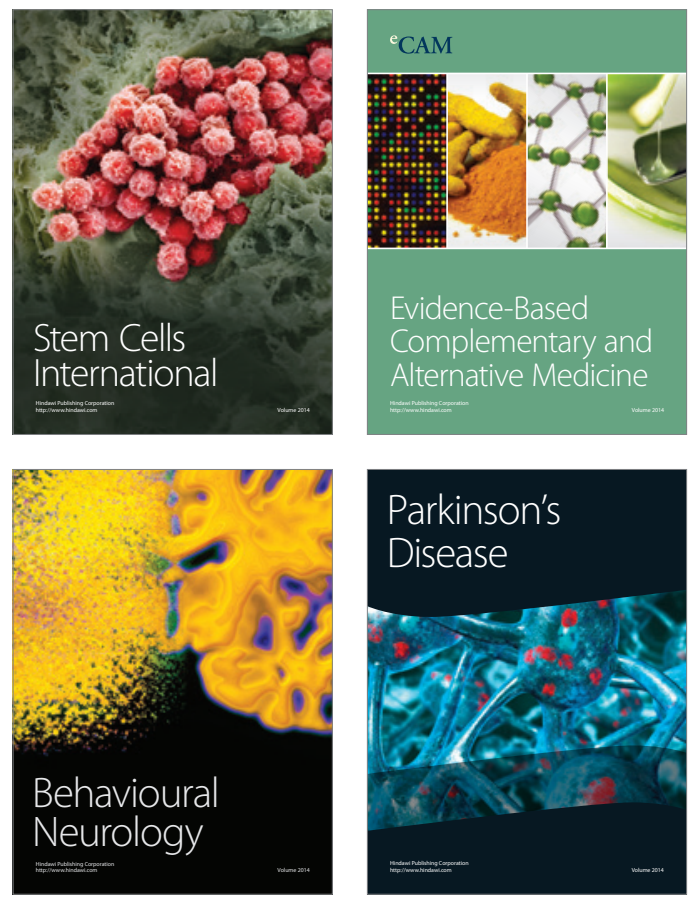
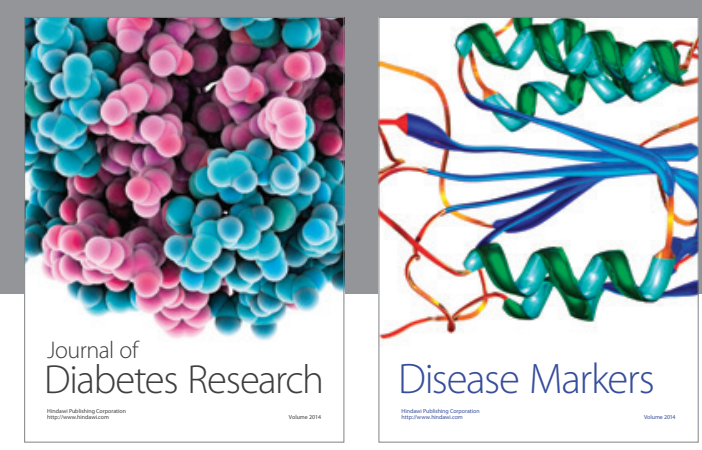

Disease Markers
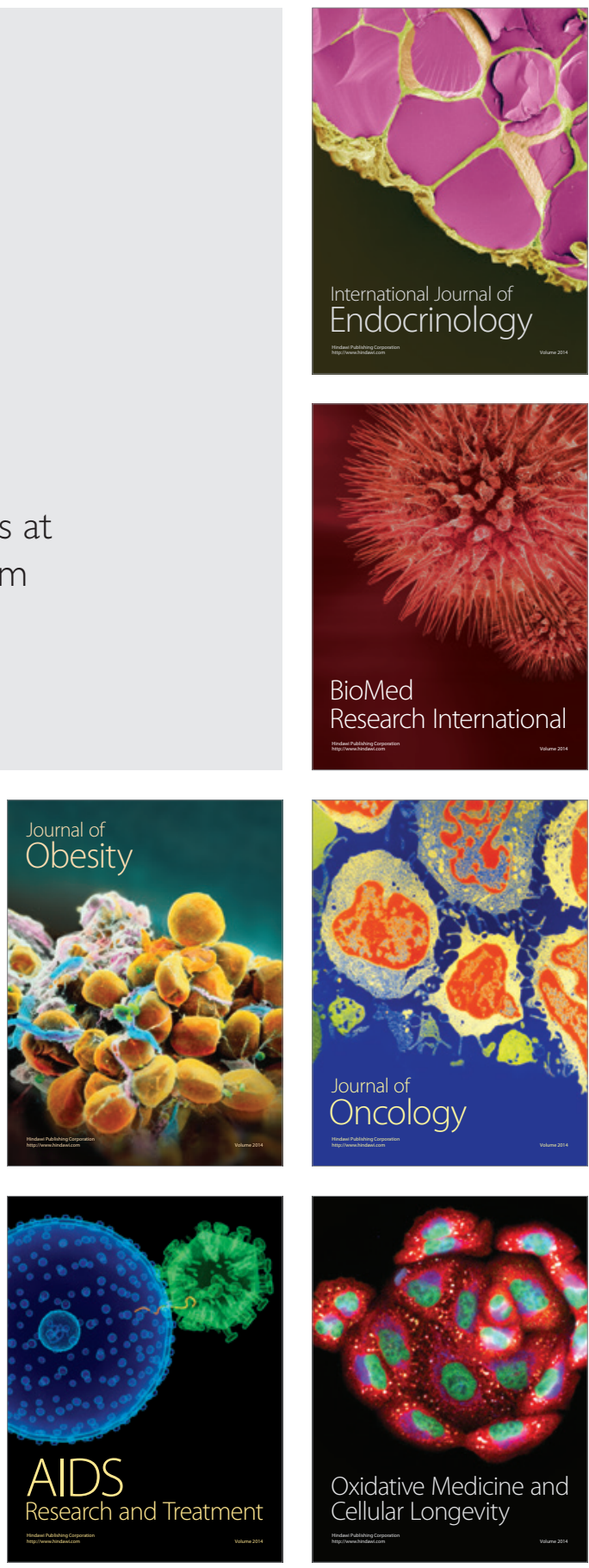